UDC 37.01.956

\title{
CAREER LEARNING AND DEVELOPMENT IN CITY TECHNOLOGY COLLEGES OF ENGLAND
}

\author{
H. R. Voronina \\ Kyiv, National Technical University of Ukraine "Kyiv Polytechnic Institute" \\ vor_ann@mail.ru
}

\begin{abstract}
Personality development is considered to be one of the most important issues in modern society. Schools play crucial role in career learning and development therefore they have to provide pupils opportunities to experience the world of work. To ensure that education in England meets current needs of young people the Government is taking necessary steps to increase career understanding and future employability. This paper deals with the development of specialized education in England. It highlights current options for the students' successful progress in the future. To the extent that career learning and development have become a vital component of secondary school curriculum the paper focuses on the process of work-related learning and career education in England. It also observes modern approaches to specialized education and analyses the development of City Technology Colleges of England which have become a successful combination of academic learning and vocational training. It is pointed to the fact that local business and industries play an important role in majority of CTC decisions including financial support and curriculum planning. The peculiarities of career learning and developing in City Technology Colleges are examined and the innovative concept of skill-based learning that provides proper working conditions for future specialists is discussed.
\end{abstract}

Key words: specialized education in England, career learning and development, vocational training, specialist school, City Technology College.

Introduction. Modern education regards students with individual peculiarities as the prior value of society. The development of creative personal potential and its fulfilment in future profession attracts scientists and teachers. The problem of specialized education takes the preliminary place in modern pedagogy. Globalisation changes society at high rate and influences greatly on the development of education that needs significant reformation to integrate effectively in world community.

Educational institutions of Ukraine have been modified inside and outside the system over the past decades. The great attention is drawn to the concept of studying while the content and the teaching methods are gradually being improved. Reforms in the system of education in our country may successfully be introduced only in case of profound examination and well-balanced implementation of relevant innovative teaching and learning technologies that work in developed countries at all levels of school and university education.

One of the main reasons for the shortage of high qualified specialists is the absence of direct links between the educational institution and the enterprise where school leavers are going to work therefore proper cooperation and interaction between them may be beneficial for both sides. According to leading experts the raising standards of technical, practical and vocational education will provide outstanding conditions for career learning and development in secondary school.

The list of the most urgent problems in education includes the necessity to establish close links between learning process and real working requirements to the future specialist. All the activities that encourage students to develop their future career have to become the core part of secondary and high school curriculum. Specialized education needs to be thoroughly examined in order to update the concept of modern school. The factors that affect the development of professional skills and experience should be analysed and the appropriate recommendations for the implementation of the positive tendencies have to be formulated.

Review of previous research. In order to understand the effectiveness of modern approaches to career learning and development in secondary schools in England we have researched the available literature and scientific works on the system of education in Britain written by I. O. Litsenko, O. I. Lokshina, O. V. Matvienko, L. P. Ryabova, A. A. Sbrueva, B. L. Wulson. Modern system of specialized education in Britain was studied by N. M. Avshenyuk, L. A. Glazunova, O. A. Gogua, T. K. Kuchay, L. P. Puhovskaya, O. V. Voloshina. Problems of specialized education were defined by A. L. Fedoruk, I. V. Gavrish, K. V. Garashchuk, 
L. M. Lyashenko, M. O. Shutova, S. I. Sinenko. Ukrainian scientists analyze present day tendencies of specialized education in order to formulate general recommendations for implementation the most effective ways of future specialist training into the process of school learning: N. L. Kostenko gives the detailed examination of specialized education organization in British schools; N. I. Balatska introduces the retrospective analysis of basic developing stages in specialized education in Britain comparing English and Ukrainian schools.

Along with that, a preview of the subject would be incomplete without analysis of foreign literature devoted to the school career learning and development in Britain. Historical retrospective of specialist schools establishment were analyzed by F. Castle and J. Evans. A number of school career guides were developed to raise the level of career education in Britain and improve the future specialist employability by D. Andrew, T. Dolfin, T. Holley, A. Watts, A. Wolf and others.

The appropriate analysis of scientific resources has proved that the problem of specialized education in England is in the centre of teaching community interest. Though it has been revealed that the innovative type of specialist school such as City Technology College needs to be examined. Therefore, the aim of the paper is to highlight the prospects of specialized education in City Technology Colleges, to study out the ways of successful combination of academic learning and working experience, to identify modern approaches to the school career learning and development in England.

The process of specialized education development. Recent changes in educational system of Britain are introduced by such a key innovation as specialist schools. 2380 specialist schools have been opened that makes up $75 \%$ of all secondary comprehensive schools by 2005 . The rest $25 \%$ are planned to be transformed into specialist schools within the following years [5]. Most specialist schools are major in technology, languages, arts, sports, mathematics, computer sciences, engineering and music. Progress and society demands not only change but also enlarge school specializations.

A brief retrospective analysis has shown that technology schools were the first specialist schools in Britain. In the period from 1988 to 1994 forty two technology schools were in Britain. The next introduced specializations were languages, arts and sports. Since 2002 a large number of business, mathematics and computer specialist schools have been opened. According to the statistics it can be concluded that technology schools take the leading place in the list of specialist schools over the past decades [5]. The detailed studying of their peculiarities will make particular contribution to the providing proper conditions for personal and professional development of future Ukrainian specialists in modern technological environment.

High level of requirements to practical learning is constantly controlled by the British government that raises school standards. Present day system of education has been reformed significantly for the last decades. The process of specialized education improvement was launched by the Industrial Training Act 1964 which framed social and economic requirements to the future specialists. It listed all the professions in-demand according to relevant qualifications and created local school authorities [11]. The Education Reforms in 1988 introduced the next important step in governmental initiatives aimed to implement National curriculum and define core subjects determining appropriate academic achievements. According to The Education Reform Act 1988 the City Technology Program was established [9]. As the result, 15 City Technology Colleges (CTC) were opened in the period from 1988 to 1993 in urban areas across England. The initial purpose of CTC was to improve the level of education and provide a strong technical element for secondary school pupils aged 11-18. CTCs became the successful combination of academic learning and working experience which brought numerous opportunities. Nowadays they offer the extraordinary chance to get a personal and professional development in modern technological environment.

The brief overview of City Technology Colleges. CTCs specialize in technical subjects that offer excellent career prospects both in local and international labor market. Each of them is sponsored by local employers who help design and deliver the curriculum which combine core subjects with vocational training. The financial support from local enterprises encourages both students and teachers to progress. Parents play an important role in the majority of decision making. 
These vocationally focused schools operate outside of local authority control and provide academic courses as well as skill-based learning [8].

CTCs promote scientific and technological educational culture with strong emphasis on practical skills. For the pupils up to 16 broad education of the National Curriculum is provided. They learn subjects such as English, Mathematics, Science, Languages, History, Geography, Art Design Technology, Music and Drama, Physical Education and Religious Studies though most of these disciplines are taught in the context of chosen specialism. Pupils are encouraged to participate in a number of competitions and projects which provide invaluable experience and give them an insight into the real world of work. Educational visits, field trips, pupils' exchange programs not only develop young people's personal skills but also broaden the range of the qualifications whereas up to date equipment helps pupils to learn effectively.

The pupils after 16 are aimed at increased specialism though they still study core curriculum subjects. It allows young people to be both technologically skilled and well-educated for further higher education or training. Individual planning ensures that teaching responds to pupils' needs. Extra time on Mathematics, Science and Technology enables them to take full advantages of the National Curriculum. Close relationships with local enterprises ensure job readiness and develop an understanding of industry and commerce. All pupils can receive help from the Career Department until they have found suitable employment.

To improve pupil performance at secondary schools the British government continued to launch new projects and introduce educational initiatives. The first CTC Kingshurst opened in 1988 within 10 years was converted to Academy. This tendency became rather popular among other CTCs therefore since 2003 most of them have obtained Academy status as they equip students both with realistic working skills and the foundations for higher education [10]. Only three of them (BRIT School, Emmanuel CTC and Thomas Telford School) remain CTCs. They differ from academies in the way that the CTCs can select more than $10 \%$ of pupils by ability whereas academies cannot. Being sponsored by leading local universities and business city academies are directly funded by the Education Department of England and follow the broad and balanced curriculum specializing in employment focused subjects.

Peculiarities of career learning and developing in City Technology Colleges. As CTCs are independent free secondary schools they are allowed to test out innovative teaching and learning technologies successfully exploring and developing the use of computer technologies and distance learning in teaching process. The process of learning in CTC is organized in a special way to maximize student performance in all forms due to removing the artificial barrier that exists between vocational and academic courses [4]. Professional development programme includes career education, work-based learning time and stress management, study skills, completing application forms, updating $\mathrm{CV}$ and interview techniques. What is more it provides open access to individual career guidance from school staff to enable pupils to develop the abilities and skills necessary for their future education and employment. Teacher of the Career Department recommend the best combination of subjects for different careers and support for job search, application and interview preparing.

All CTCs have close links with local employers who play an active role in career learning and development donating necessary equipment and providing workplaces for pupils. The partnership with industry is a key feature of career learning and development in CTC as pupils are involved in diversity of work projects for local enterprises and have regularly contacts with them. Financial help is combined with the curriculum design and delivery what makes this alliance beneficial to both sides. The business is interested in high qualifications of future specialists therefore CTCs organize the vocational training directly at the local enterprises while pupils obtain up-to-date information on career opportunities which enables them to make decisions about the future employment. 
Career education programs in CTCs are planned in order to provide pupils opportunities to apply their knowledge and skills in realistic working conditions where safe and secure environment is primarily concerned. The educational entitlement irrespective of religion, gender or special needs is ensured for pupils of all abilities as one of the prior school objectives.

Conclusions. In this paper a viewpoint on career learning and development in specialist schools has been provided. The concept of specialized education is influenced by different factors which make the requirements to modern specialists rise. Due to historical aspects and the successful reforms the system of specialized education in England takes the leading position in professional world. In view of diversity of specialist schools, we have laid emphasis on City Technology Colleges as they are an outstanding example of combining academic and vocation studies in secondary school teaching subjects of National Curriculum with a specific focus on science and technology. This innovative concept of practical teaching should be definitely taken into consideration while organizing career learning and development.

On the whole the further research of this issue will help to solve the problem of providing proper working conditions for future specialists and take a positive step toward actual changes in school life which will result in beneficial reformation of specialized education in Ukraine.

\section{REFERENCES}

1. Балацька Н.І. Професійна орієнтація учнів у сучасних середніх школах Англії : автореф. дис. ... канд.. пед.. наук: 13.00.01 / Н.І. Балацька. - К., 2004. - 23 с.

2. Костенко Н. І. Організація профільного навчання у старшій школі Великої Британії : автореф. дис. ... канд.. пед.. наук: 13.00.04 / Н.І.Костенко. - Кировоград, 2010. - 23 с.

3. Andrews D. The future of careers work in schools in England: what are the options? / David Andrews. A discussion paper. - 2013. - 36 p. - Retrieved from www.davidandrewsceg.co.uk

4. Brit School - National Curriculum and Options [Electronic resource] - Retrieved from https://www.brit.croydon.sch.uk/nationalcurriculum

5. Castle F. Specialist Schools - what do we know? / F. Castle, J. Evans. - L., 2006. - 34 p

6. Careers guidance and inspiration in schools. Departmental advice for governing bodies, school leaders and school staff. [Electronic resource]. - Retrieved from www.gov.uk/government/publications

7. City Technology Colleges [Electronic resource]. - Retrieved from https://www.gov.uk/types-of-school/ city-technology-colleges

8. City Technology Colleges [Electronic resource]. - Retrieved from http://web.archive.org/web/20050301211137/http://www.standards.dfes.gov.uk/academies/ctcs/?version=1

9. Education Reform Act 1988 [Electronic resource]. - Retrieved from http://www.hmso.gov.uk/acts /acts1988

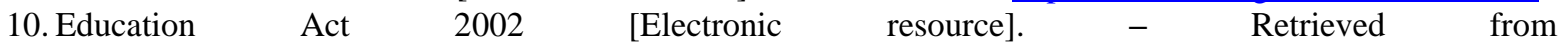
http://www.educationengland.org.uk/documents/acts/2002-education-act.pdf

$\begin{array}{llllllll}\text { 11. Industrial Training } & \text { Act } 1964 \quad \text { [Electronic } & \text { resource.] } & \text { Retrieved from }\end{array}$ http://www.legislation.gov.uk/ukpga/1964/16/enacted

\section{REFERENCES}

1. Balatska, N. I. (2004). Profession guidance in high school of Britain. Extended abstract of candidate's thesis. Kyiv [in Ukrainian].

2. Kostenko, N. I. (2010). Organization of profile-oriented education at the senior schools in Great Britain. Extended abstract of candidate's thesis. Kyiv [in Ukrainian].

3. Andrews, D. (2013). The future of careers work in schools in England: what are the options? Retrieved from www.davidandrewsceg.co.uk

4. Brit School - National Curriculum and Options. Retrieved from https://www.brit.croydon.sch.uk/nationalcurriculum

5. Castle, F., Evans, J. (2006). Specialist Schools - what do we know? London, England.

6. Careers guidance and inspiration in schools. (2014). Departmental advice for governing bodies, school leaders and school staff. Retrieved from www.gov.uk/government/publications

7. City Technology Colleges. Retrieved from https://www.gov.uk/types-of-school/city-technology-colleges

8. City Technology Colleges. Retrieved from http://www.standards.dfes.gov.uk/academies/ctcs/?version=1

9. Education Reform Act (1988). Retrieved from http://www.hmso.gov.uk/acts /acts1988

10. Education Act 2002. Retrieved from http://www.educationengland.org.uk/documents/acts/2002-education-act.pdf

11. Industrial Training Act 1964. Retrieved from http://www.legislation.gov.uk/ukpga/1964/16/enacted 
Г. Р. Вороніна. Формування професійної перспективи в міських технологічних коледжах Англії.

Одним 3 найбільш важливих питань сучасної школи є формування всебічно розвиненої особистості. Оскільки професійна перспектива починає формуватися у шкільні роки, надзвичайно відповідальним є питання забезпечення відповідних умов для практичного ознайомлення з широким спектром спеціальностей, що надасть можливість учням правильно обрати професію в майбутньому. Саме тому, у центрі уваги нашого дослідження постала система професійної освіти в Англії, що постійно контролюється з боку уряду 3 метою підвищення стандартів та покращення рівня працевлаштування випускників. У статті розглянуто особливості профільного навчання у спеціалізованих школах Англії, окреме місце серед яких займають міські технологічні коледжі. Такі середні навчальні заклади, що почали відкриватися в англійських міських регіонах у період з 1988 по 1993 роки, становлять певний науковий інтерес з точки зору інноваційного підходу до інтегрування академічного та профільного навчання. Зазначений підхід забезпечує значне наближення процесу оволодіння майбутньою професією до реальних робочих умов, з якими стикаються випускники шкіл, та трансформує навчання у практичну площину. Особливу увагу приділено продуктивній співпраці міських технологічних коледжів 3 місцевими підприємствами, які в майбутньому надають випускникам певну кількість робочих місць та безпосередньо зацікавлені в отриманні висококваліфікованих спеціалістів. У статті також представлено аналіз характерних рис процесу формування професійної перспективи у міських технологічних коледжах Англії, які за вимогою часу один за одним отримали статус академій. Подальше вивчення запропонованої теми сприятиме ефективній модернізації організації профільної освіти в Україні.

Ключові слова: професійна освіта в Англії, профільне навчання, спеціалізована школа, міський технологічний коледж, професійна перспектива.

\section{А. Р. Воронина. Формирование профессиональной перспективы в городских технологических} колледжах Англии.

Развитие личности считается одним из приоритетных заданий современного общества. Школа играет решающую роль в формировании профессиональной перспективы, обеспечивая возможности для знакомства учеников с будущими профессиями. С целью повышения стандартов профильного обучения в Англии правительство проводит мониторинг существующей системы и разрабатывает рекомендации для улучшения показателей будущего трудоустройства выпускников школ. В данной статье рассмотрен процесс развития профессионального образования в Англии, а также представлены современные технологии эффективного профильного обучения. В статье также освящены основные этапы становления специализированных школ нового типа, a именно городских технологических колледжей. Сделано попытку проанализировать особенности функционирования этих современных школ с углубленным изучением научных и технических дисциплин, которые представили инновационный подход к процессу интеграции академического образования и профильного обучения. Делается акцент на продуктивном сотрудничестве городских технологических колледжей с местными предприятиями, которые впоследствии предоставляют рабочие места для выпускников, что обеспечивает эффективное формирование практических навыков и понимание реальных требований к будущим специалистам. Обосновывается успешность освоения различных технических профессий, которая заложена в гармонично сбалансированном сочетании общих и профильных предметов.

Ключевые слова: профессиональное образование в Англии, профильное обучение, специализированная школа, городской технологический колледж, профессиональная перспектива. 